\title{
ASSOCIATION OF THE SEVERITY OF LUNG LESIONS WITH CARCASS AND MEAT QUALITY IN SLAUGHTER PIGS
}

\author{
Nedjeljko KARABASIL ${ }^{1}$, Nikola ČOBANOVIĆ ${ }^{1}$, Ivana VUČIĆEVIĆ ${ }^{2}$, Silvana STAJKOVIĆ ${ }^{1}$, \\ Zsolt BECSKEI ${ }^{3 *}$, Petra FORGÁCH ${ }^{4}$ and Sanja ALEKSIĆ-KOVAČEVIĆ ${ }^{2}$ \\ ${ }^{1}$ Department of Food Hygiene and Technology, ${ }^{2}$ Department of Pathology and \\ ${ }^{3}$ Department of Animal Breeding and Genetics, Faculty of Veterinary Medicine, \\ University of Belgrade, Bulevar Oslobodjenja 18, 11000 Belgrade, Serbia; \\ ${ }^{4}$ Department of Microbiology and Infectious Diseases, University of Veterinary \\ Medicine, Budapest, Hungary
}

(Received 14 March 2017; accepted 12 July 2017)

\begin{abstract}
The aim of this study was to determine the association of lung lesions with carcass and meat quality traits in slaughter pigs and to describe the main morphological features associated with lung lesions. Macroscopic lesions on the lungs were detected in $67.09 \%$ of a total of 79 pigs examined. Histopathological examination revealed that acute and chronic interstitial pneumonia represented the commonest changes, detected in $26.67 \%$ and $33.33 \%$ of the cases, respectively. Bronchopneumonia was found in $33.33 \%$ of the cases. By immunohistochemical examination, $26.67 \%$ of the lungs showed the presence of severe peribronchiolar and perialveolar infiltration composed predominantly of CD3+ T lymphocytes, which finding may be indicative of viral pneumonia. Regarding the production traits, it was confirmed that pigs with severe lung lesions had the lowest liveweight, hot carcass weight and meatiness, the highest $\mathrm{pH}$ value $45 \mathrm{~min}$ after slaughtering $\left(\mathrm{pH}_{45}\right)$ and the highest incidence of dark, firm, dry (DFD) and pale, soft, exudative (PSE) meat. The presence of lung lesions significantly downgraded carcass value and caused a significant deterioration in pork quality.
\end{abstract}

Key words: Lung lesions, lung histopathology, CD3+ T cell, DFD meat, PSE meat, slaughter pigs

Over the last few decades, lung lesions have represented one of the most important health and welfare issues in intensive pig farming worldwide (Flesja and Ulvesaeter, 1980; Ujvári et al., 2015; Palzer et al., 2015; Sárközi et al., 2015; Čobanović et al., 2016a; Lukač et al., 2016; Polaček and Aleksić-Kovačević, 2016). They cause significant financial losses to the pig industry, arising from reduced growth rate and feed conversion, high morbidity and mortality, increased medication costs, condemnation of offal and carcasses, and lower carcass quality (Ostanello et al., 2007; Becskei et al., 2010; Fraile et al., 2010; Toplak et

*Corresponding author; E-mail: beckeizolt@gmail.com; Phone/Fax: 00381 (112) 685-653 
al., 2012; Čobanović et al., 2015; Štukelj et al., 2015; Szeredi et al., 2015). In most cases, respiratory diseases occur in subclinical form and, therefore, a clinical examination on the farm of origin cannot be regarded as an efficient method for their assessment (Ostanello et al., 2007). Therefore, the evaluation of lung lesions at the slaughter line is a valuable tool for estimating the incidence and severity of subclinical respiratory infections on herd level, using macroscopically visible pathological changes as indicators of disease (Fraile et al., 2010). Laboratory tests can also be useful in detecting subclinical lung lesions at slaughterhouse level (Ostanello et al., 2007), whereby it is a common practice to combine lung lesion scoring with PCR, culture, immunohistochemistry and/or histopathology (Hillen et al., 2014).

Several studies have revealed that pork quality is affected by many different factors, such as genetic variables, feeding, slaughter weight, gender as well as pre-slaughter and slaughter conditions (Karabasil et al., 2013a,b; Adamović et al., 2014; Čobanović et al., 2016b,c). However, only few papers have been published about the relationship between respiratory lesions and pork quality (Minkus et al., 2004; Dailidavičienė et al., 2008, 2009; Permentier et al., 2015). Some authors have found that lung lesions can increase the tendency towards dark, firm and dry (DFD) meat (Minkus et al., 2004; Dailidavičienè et al., 2008, 2009), while others reported that lung lesions can contribute to the increased incidence of pale, soft and exudative (PSE) meat (Permentier et al., 2015). Therefore, the aim of this study was to determine the influence of lung lesions on carcass and meat quality traits in slaughter pigs and to describe the main morphological features associated with these lesions.

\section{Materials and methods}

\section{Experimental animals}

The study was conducted on five days between December 2015 and January 2016 on 79 fattening pigs (about six months old, with an average live weight of $115.30 \pm 3.22 \mathrm{~kg}$ ) slaughtered in a low-input abattoir, with a weekly throughput of about 100 pigs. All the animals were of the same breed (Yorkshire $\times$ Landrace crossbreeds) and originated from a single commercial farm. The animals were fattened in a finishing barn on a fully slatted floor, in groups of 20 individuals in each pen, with an average space allocation of $1 \mathrm{~m}^{2}$ per pig. The farm had a history of increased occurrence of pneumonia. On the farm, there was no ongoing vaccination programme against respiratory diseases. The treatment conditions, both before and after slaughter, were identical for all pigs and in accordance with conventional industrial practice. 


\section{Macroscopic lung lesions}

The lungs of all the pigs examined were evaluated for macroscopically visible lesions based on the method described by Madec and Kobisch (1982). Pneumonic lesions were scored at the individual level using a five-point scale ( 0 to 4 ) on each of the seven lobes depending on the percentage of the lobe affected, where 0 was given if the lobe was without lesions, a score of 1 if the lesion affected less than $25 \%$ of the lobe surface, a score of 2 was awarded when the lesion affected between $25 \%$ and $50 \%$ of the lobe surface, a score of 3 if the lesion affected between $50 \%$ and $95 \%$ of the lobe surface, and a score of 4 was given when the lesion affected more than $95 \%$ of the lobe surface. The score of the lungs was calculated based on the sum of the scores for each of the seven lobes. The lung was scored as 0 when no lesion was present. Scores 1 to 4 indicated mild pneumonia, a score $\geq 5 / 28$ was regarded as moderate to severe pneumonia. Pleurisy was scored at the individual level using a five-point scale (0 to 4), where 0 was given if the lung was without lesions, a score of 1 indicated one pleural adhesion between or at the border of a lung lobe, a score of 2 indicated focal lesions with several pleural adhesions between lung lobes, a score of 3 indicated extensive parietal adhesions of the lung with the thoracic wall, and a score of 4 indicated extensive pleurisy when the entire lung was fixed to the thoracic wall. A score of 1 indicated mild pleurisy, while scores $\geq 2 / 4$ were indicative of moderate to severe pleurisy (Fablet et al., 2012). Also, any signs of congestion or enlargement of the tracheobronchial and mediastinal lymph nodes were noted as present or absent.

\section{Histopathology}

To assess the pathological lesions, samples were taken for further histopathology from every fifth lung at the slaughter line. A total of 15 lungs were analysed whereby samples were taken from the lesions and also from the macroscopically healthy lung tissue. Samples were fixed in $10 \%$ neutral buffered formalin for routine histopathological evaluation. Tissues were processed routinely in a LEICA TP1020 automatic tissue processor, embedded in paraffin, and cut at $4 \mu \mathrm{m}$. Initial sections were stained with haematoxylin and eosin (HE) and analysed by light microscope (BX51, Olympus Optical, Japan).

\section{Immunohistochemistry}

Immunohistochemical (IHC) staining was performed on formalin-fixed and paraffin-embedded $4-\mu \mathrm{m}$-thick tissue sections. As primary antibody CD3+ T cell (Dako, A0452) diluted 1:50 in PBS was used. The sections were incubated in a microwave oven at $560 \mathrm{~W}$ for $21 \mathrm{~min}$ in citrate buffer $(\mathrm{pH} \mathrm{6.0)}$ ) and then treated with methanol containing $0.3 \%$ hydrogen peroxide for $15 \mathrm{~min}$ at room temperature to inactivate endogenous peroxidase. In order to avoid the nonspecific bind- 
ing of secondary antibodies, the sections were incubated with $50 \%$ normal goat serum in PBS for 20 min (Polaček et al., 2007). After antigen retrieval and inactivation of endogenous peroxidase, the sections were incubated with primary antibody for one hour in a humid chamber at room temperature $\left(22 \pm 3{ }^{\circ} \mathrm{C}\right)$. A streptavidin-immunoperoxidase staining procedure (Dako) was used for immunolabeling. The reaction was visualised using $\mathrm{DAB}+(3,3$ '-diaminobenzidine tetrahydrochloride, DAKO, K3468). Mayer's haematoxylin was used for counterstaining. Aqueous medium glycergel (DAKO, C563) was used in the stained sections for mounting. For validation of the staining procedure, appropriate controls (positive and negative) were used. Slides were evaluated by light microscope (BX51, Olympus Optical, Japan).

Digital images of the histopathological and immunohistochemical slides were taken using an Olympus BX51 optical microscope with an Olympus Color View III digital camera.

\section{Carcass and meat quality analyses}

The carcasses were weighed immediately after splitting and final washing to obtain the hot carcass weight, and re-weighed $24 \mathrm{~h}$ after chilling to determine the weight of the cooled carcass. The dressing percentage was calculated as (hot carcass weight $\div$ live weight $) \times 100$. A single fat thickness measurement at each of two carcass points (between the 13th and 15th dorsal vertebrae on the back, and over the m. gluteus medius at the sacrum) was determined in all carcasses using a metal ruler (with an accuracy of $1.0 \mathrm{~mm}$ ). Meatiness (\%) was calculated according to the Official Gazette (1985) based on the sum of backfat thickness at two points and the hot carcass weight. A Testo 205 portable $\mathrm{pH}$ meter (Testo AG, Lenzkirch, Germany) was used to measure meat $\mathrm{pH}$ and temperature $45 \mathrm{~min}$ post mortem on the $m$. longissimus dorsi, pars lumbalis, on the left half of the carcass, at the level of the 10th and 11th ribs. Meat quality traits were both measured in duplicate, and the average of the two measurements was taken as the final result. The carcasses showing $\mathrm{pH}_{45}$ values lower than 6.0 were classified as PSE meat, while those with $\mathrm{pH}_{45}$ values higher than 6.4 were classified as DFD meat (Adzitey and Nurul, 2011). Carcasses with a $\mathrm{pH}_{45}$ between 6.0 and 6.4 were classified as pork of normal quality.

\section{Statistical analysis}

All data were analysed using statistical software SPSS (2015) version 23.00. Based on severity of macroscopic lung lesions pigs were classified into three groups: no lung lesions - pigs without macroscopic lung lesions; moderate to severe lung lesions - pigs with a pneumonia score between 0 and 4 and/or pleurisy score 1; and severe lung lesions - pigs with a pneumonia score $\geq 5$ and/or a pleurisy score $\geq 2$. Based on the severity of histological alterations, all 
observed microscopic changes were scored using a three-point scale according to Hillen et al. (2014), and the pigs $(n=15)$ were divided into three groups: without alterations - pigs without microscopic lung lesions; mild alterations - pigs with mild alterations (single cells) of the lungs; and moderate to severe alterations pigs with marked to severe alterations of the lungs. Data were described by descriptive statistical parameters as the mean value and standard error of the mean. One-way ANOVA was performed to test the effect of lung lesion severity on carcass and meat quality traits. Means significantly different at $\mathrm{P}<0.05$ were further compared using the Tukey's post-hoc test (multiple comparisons). The incidence of pork quality classes according to the severity of lung lesions was determined by Chi-square test. Pearson correlations were calculated to determine the relationship between lung lesion score and carcass and meat quality traits. Values of $\mathrm{P}<0.05$ were considered significant.

\section{Results}

Only $32.91 \%$ of the 79 lungs examined had no visible macroscopic lung lesions (Fig. 1A), while 53 pigs $(67.09 \%)$ displayed pneumonia alone or in combination with pleurisy followed by enlargement of the mediastinal lymph nodes. Varying degrees and types of lung lesions were observed in the pigs examined (Fig. 1B). Tables 1 and 2 show the prevalence and severity of macroscopic and microscopic lung lesions in the pig carcasses examined. Mild and moderate to severe pneumonia, often with consolidation of the cranial lobes, was commonly observed in the pigs examined, while mild and moderate to severe pleurisy was less often recorded.

Histopathological examination revealed the presence of mononuclear cell infiltrate in the interstitium, bronchiolar and alveolar exudates, emphysema, hyperaemia and oedema, as well as haemorrhages. Pulmonary tissue alterations observed in the lungs of $26.67 \%$ of the 15 sampled animals during acute interstitial pneumonia consisted of hyperaemia, oedema and mononuclear cell accumulation in the alveolar interstitium which caused further thickening of the alveolar wall. The alveolar airspaces were reduced. Also, hyaline membranes and desquamated pneumocytes of type I were present. Chronic interstitial pneumonia was found in $33.33 \%$ of the cases. It was characterised by mononuclear cell accumulation in the interstitium, the presence of type II hyperplastic pneumocytes in the lumen of alveoli, and initial fibrosis. In addition, hyperplasia of the peribronchiolar lymphatic tissue was evident (Fig. 1C). Microscopic findings revealed mainly interstitial pneumonia. However, almost $30 \%$ of animals with a detected interstitial pneumonia also had mucopurulent bronchopneumonia, probably as a result of secondary bacterial infection. The inflammation varied in severity from lung to lung, but it was moderate to severe in most cases. According to our examination, $26.67 \%$ of the examined lungs showed the presence of severe peribronchiolar and 


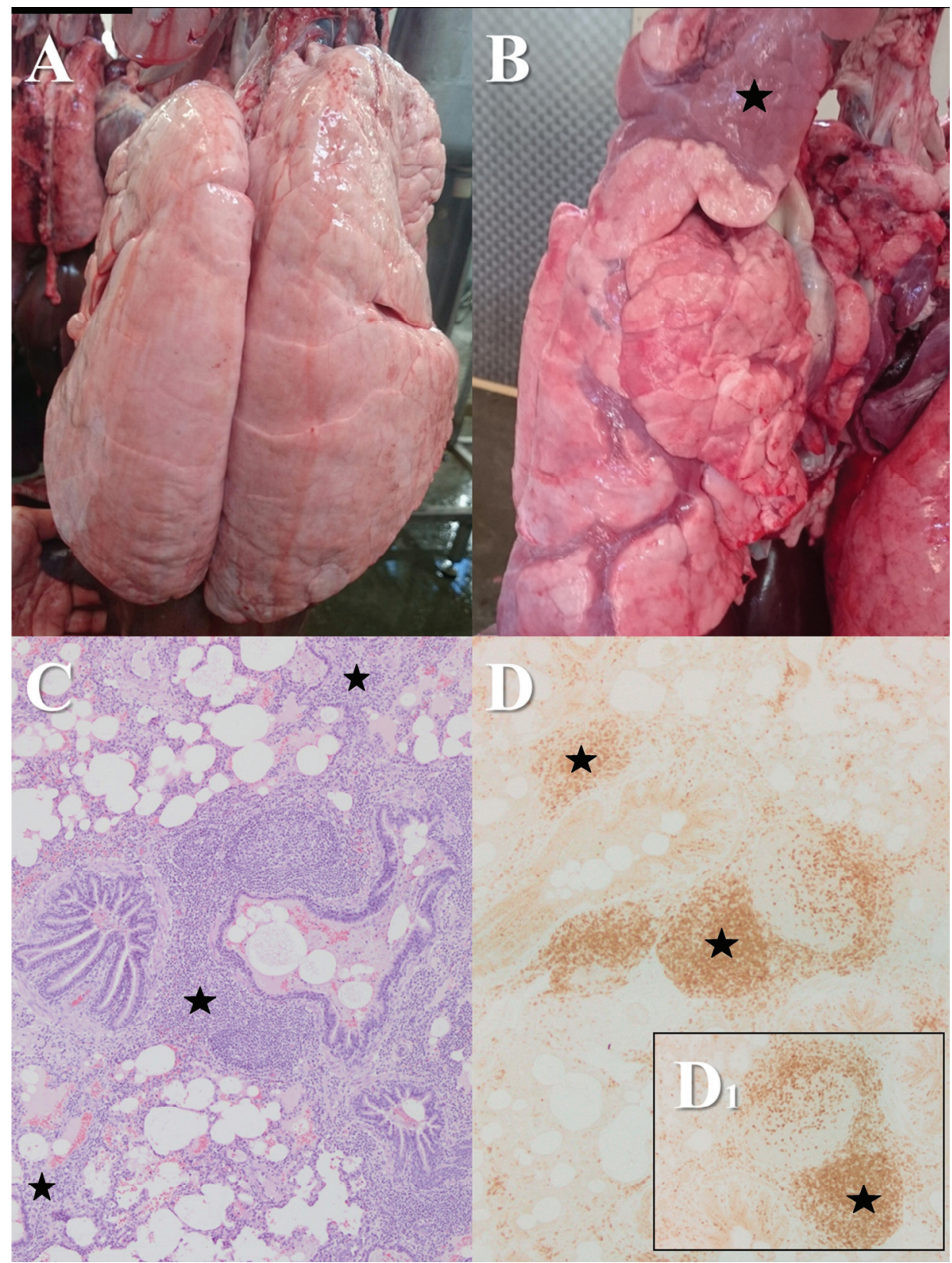

Fig. 1. Morphological changes associated with lung lesions. (A) Lung of a pig without lesions. (B) Lung of a tested pig with severe gross lesions. Dark purple consolidation of the cranial lung lobe (star). (C) Severe interstitial pneumonia with marked peribronchiolar and perialveolar mononuclear cell infiltration (stars). Haematoxylin and eosin $(\mathrm{HE}), \times 100 .\left(\mathrm{D}, \mathrm{D}_{1}\right)$ Severe mononuclear cell infiltrates in the interstitium, composed predominantly of CD3+ T lymphocytes (stars). Immunohistochemistry (IHC), $\times 100$ and $\times 200$ 
perialveolar infiltration, composed predominantly of CD3+ T lymphocytes (Fig. 1D), which could be indicative of a viral aetiology. Marked emphysema was observed in $46.67 \%$ of the lungs. However, moderate to severe hyperaemia and oedema were present in $6.67 \%$ and moderate to severe haemorrhages in $20.00 \%$ of the lungs examined (Table 2).

\section{Table 1}

Prevalence and severity of macroscopic lung lesions in the pig carcasses examined $(n=79)$

\begin{tabular}{lcc}
\hline & Number of pigs & Percentage of pigs \\
\hline Pneumonia & 53 & 67.09 \\
No pneumonia & 26 & 32.91 \\
Mild pneumonia & 31 & 39.24 \\
Moderate to severe pneumonia & 22 & 27.85 \\
Pleurisy & 13 & 16.46 \\
No pleurisy & 66 & 83.54 \\
Mild pleurisy & 4 & 5.06 \\
Moderate to severe pleurisy & 9 & 11.40 \\
\hline
\end{tabular}

No pneumonia/pleurisy: pigs without lung lesions (score 0); Mild pneumonia: pigs with a pneumonia score of 1 to 4; Moderate to severe pneumonia: pigs with a pneumonia score of $\geq 5$; Mild pleurisy: pigs with a pleurisy score of 1 ; Moderate to severe pleurisy: pigs with a pleurisy score of $\geq 2$

Table 2

Histopathological lesions found in the lungs examined $(\mathrm{n}=15)$

\begin{tabular}{|c|c|c|c|c|}
\hline & \multicolumn{2}{|c|}{ Mild lesions } & \multicolumn{2}{|c|}{ Moderate to severe lesions } \\
\hline & $\mathrm{n}$ & $\%$ & $\mathrm{n}$ & $\%$ \\
\hline Mononuclear cell infiltrates in the interstitium & 5 & 33.33 & 4 & 26.67 \\
\hline Bronchiolar and alveolar exudates & 4 & 26.67 & 1 & 6.67 \\
\hline Emphysema & 3 & 20.00 & 7 & 46.67 \\
\hline Hyperaemia and oedema & 1 & 6.67 & 1 & 6.67 \\
\hline Haemorrhage & 1 & 6.67 & 3 & 20.00 \\
\hline
\end{tabular}

Mild lesions: pigs with mild alterations (single cells) of the lungs; Moderate to severe lesions: pigs with marked to severe alterations of the lungs

The mean values of carcass and meat quality traits and the incidence of pork quality classes according to lung lesion severity are summarised in Table 3. Pigs having mild and moderate to severe lung lesions had a significantly lower liveweight, hot and cold carcass weights and meatiness $(\mathrm{P}<0.05)$. The same groups of pigs had a significantly higher $\mathrm{pH}_{45}$ value and incidence of DFD meat $(\mathrm{P}<0.05)$. A significant correlation was found between pneumonia and pleurisy scores and liveweight $(r=-0.83$ and $r=-0.68)$, hot carcass weight $(r=-0.76$ 
and $\mathrm{r}=-0.64)$, cold carcass weight $(\mathrm{r}=-0.71$ and $\mathrm{r}=-0.63)$, fat thickness on the back $(r=0.44$ and $r=0.28)$ and at the sacrum $(r=0.61$ and $r=0.35)$, meatiness $(\mathrm{r}=-0.61$ and $\mathrm{r}=-0.34)$ and $\mathrm{pH}_{45}$ value $(\mathrm{r}=0.52$ and $\mathrm{r}=0.35)(\mathrm{P}<0.05$, data not shown).

\section{Table 3}

Mean values ( \pm standard error of the mean) of carcass and meat quality traits, and the incidence of pork quality classes according to the severity of lung lesions $(n=79)$

\begin{tabular}{lcccc}
\hline Variable & $\begin{array}{c}\text { No lung } \\
\text { lesions }\end{array}$ & $\begin{array}{c}\text { Mild lung } \\
\text { lesions }\end{array}$ & $\begin{array}{c}\text { Moderate to } \\
\text { severe lung } \\
\text { lesions }\end{array}$ & Significance \\
\hline Number of pigs & 26 & 31 & 22 & \\
Carcass quality & & & & \\
Live weight $(\mathrm{kg})$ & $118.00 \pm 0.37^{\mathrm{a}}$ & $115.10 \pm 0.32^{\mathrm{b}}$ & $112.50 \pm 0.74^{\mathrm{c}}$ & $*$ \\
Hot carcass weight $(\mathrm{kg})$ & $97.07 \pm 0.40^{\mathrm{a}}$ & $94.33 \pm 0.44^{\mathrm{b}}$ & $92.00 \pm 0.87^{\mathrm{c}}$ & $*$ \\
Cold carcass weight $(\mathrm{kg})$ & $94.68 \pm 0.44^{\mathrm{a}}$ & $91.97 \pm 0.47^{\mathrm{b}}$ & $90.06 \pm 0.86^{\mathrm{b}}$ & $*$ \\
Dressing percentage $(\%)$ & $82.24 \pm 0.26$ & $81.95 \pm 0.24$ & $81.73 \pm 0.37$ & NS \\
FTB (mm) & $17.42 \pm 1.42^{\mathrm{a}}$ & $21.94 \pm 1.42^{\mathrm{b}}$ & $28.55 \pm 1.15^{\mathrm{c}}$ & $*$ \\
FTS (mm) & $27.27 \pm 3.75^{\mathrm{a}}$ & $43.00 \pm 3.22^{\mathrm{b}}$ & $63.50 \pm 1.93^{\mathrm{c}}$ & $*$ \\
Meatiness $(\%)$ & $42.59 \pm 0.99^{\mathrm{a}}$ & $38.19 \pm 0.92^{\mathrm{b}}$ & $32.45 \pm 0.44^{\mathrm{c}}$ & $*$ \\
Meat quality & & & & \\
pH & & & & $*$ \\
$\mathrm{~T}_{45}\left({ }^{\circ} \mathrm{C}\right)$ & $6.16 \pm 0.03^{\mathrm{a}}$ & $6.27 \pm 0.02^{\mathrm{b}}$ & $6.41 \pm 0.24^{\mathrm{c}}$ & $*$ \\
Pork quality classes $(\%)$ & $38.71 \pm 0.18$ & $38.62 \pm 0.13$ & $38.76 \pm 0.15$ & NS \\
PSE & & & & $*$ \\
Normal & $3.85^{\mathrm{a}}$ & $3.23^{\mathrm{a}}$ & $22.73^{\mathrm{b}}$ & $*$ \\
DFD & $92.31^{\mathrm{a}}$ & $70.97^{\mathrm{b}}$ & $18.18^{\mathrm{c}}$ & $*$ \\
\hline
\end{tabular}

No lung lesions: pigs without lung lesions; Mild lung lesions: pigs with pneumonia scores 1 to 4 and/or a pleurisy score of 1; Moderate to severe lung lesions: pigs with a pneumonia score of $\geq 5$ and/or a pleurisy score of $\geq 2$. FTB: fat carcass thickness on the back; FTS: fat carcass thickness at the sacrum. $\mathrm{pH}_{45}$ : meat $\mathrm{pH}$ values measured 45 minutes post mortem; $\mathrm{T}_{45}$ : meat temperature measured 45 minutes post mortem. DFD meat: $\mathrm{pH}_{45}>6.4$; Normal meat: $\mathrm{pH}_{45}$ between 6.0 and 6.4; PSE meat: $\mathrm{pH}_{45}<6$. ${ }^{*}$ Statistical significance at $\mathrm{P}<0.05$; NS: not significant $(\mathrm{P}>0.05)$. Different letters in the same row indicate a significant difference at $\mathrm{P}<0.05^{(\mathrm{a}-\mathrm{c})}$

\section{Discussion}

The assessment of lung lesions revealed a high prevalence of pneumonia and pleurisy in the pigs examined. Despite the fact that the investigation was carried out in winter, when the seasonal risk is increased (van Staaveren et al., 2016), the prevalence of pigs with different degrees of lung lesions was comparable to the results of Hillen et al. (2014), who reported that $35.6 \%$ and $20.3 \%$ of the pigs were found to have mild and severe pneumonia, respectively. Furthermore, van 
Staaveren et al. (2016) reported that $44.8 \%, 8.6 \%$ and $4.8 \%$ of the pigs had mild, moderate and severe pneumonia, while $22.4 \%$ and $22.8 \%$ of the pigs were found to have mild and severe pleurisy, respectively. In our study, the microscopic findings most often revealed acute or subacute-chronic interstitial pneumonia. However, $33.33 \%$ of the animals with a detected interstitial pneumonia also had a mucopurulent bronchopneumonia, probably as a result of secondary bacterial or mycoplasma infection, which mainly affects the cranioventral lobes in the form of consolidation.

Lung lesions are often associated with suboptimal production systems and indicate the presence of health problems affecting the pig welfare on the farm of origin (Harley et al., 2012). Consequently, the meat industry suffers indirect losses of viscera and carcass condemnation and extensive trimming through the reduction in slaughter line speed for a more detailed inspection of suspicious carcasses, and disposal of organs unsuitable for human consumption (Harley et al., 2012; Teixeira et al., 2016).

In this study, pigs with moderate to severe lung lesions had the lowest liveweight, hot carcass weight and meatiness $(\mathrm{P}<0.05)$ (Table 3). These results were strengthened because in this investigation the increase in pneumonia and pleurisy score resulted in a decreased liveweight, hot carcass weight, cold carcass weight and meatiness $(\mathrm{P}<0.05)$. Several studies reported that the presence of severe lung lesions in slaughter pigs resulted in reduced liveweight (Henninger et al., 2014), hot carcass weight (Minkus et al., 2004; Permentier et al., 2015) and cold carcass weight (Teixeira et al., 2016). This could be attributed to the fact that growth rate, feed conversion and daily weight gain during the fattening period were significantly reduced in pigs with respiratory lesions (Donkó et al., 2005). During the period of sickness, pigs consume less food than they need, and therefore they are not able to express their maximum genetic potential for muscle protein synthesis (Šoltésová et al., 2015). Instead of utilising nutrients to increase body mass during the fattening period, the presence of respiratory infection leads to a reduction in muscle and fat tissue synthesis and increases the degradation rates of these tissues, which results in the repartitioning of nutrients toward areas that have a greater need (Šoltésová et al., 2015). Consequently, these metabolic alterations induce a reduction in body weight and significantly downgrade carcass quality (Ostanello et al., 2007; Čobanović et al., 2016a).

The current research underlined that pigs with moderate to severe lung lesions had the highest incidence of PSE meat $(\mathrm{P}<0.05)$ (Table 3). Likewise, Permentier et al. (2015) found a six times greater risk of obtaining PSE meat in pigs with a high lung lesion score than in those with low lung lesion score. In contrast, Minkus et al. (2004) detected PSE meat in only $1.1 \%$ of pigs with lung lesions. In this investigation, the highest $\mathrm{pH}_{45}$ value and incidence of DFD meat were recorded in pigs with moderate to severe lung lesions $(\mathrm{P}<0.05$, Table 3$)$. Similar results were reported by Minkus et al. (2004), who found that $87 \%$ of 
pigs with lung lesions produced DFD meat, while the incidence of DFD meat in pigs without lung lesions was only 1.8\%. Dailidavičienè et al. (2008) emphasised that pigs during the period of sickness need a higher amount of energy which leads to a reduction of glycogen and adenosine triphosphate reservoirs in the muscles post mortem, resulting in a lower production of lactic acid and a higher meat $\mathrm{pH}$ value which increase the tendency towards DFD meat. This tendency was also confirmed in the present study, where increased pneumonia and pleurisy scores were associated with significantly increased $\mathrm{pH}_{45}$ values $(\mathrm{P}<0.05)$. It has been reported that the presence of lung lesions in pigs can lead to some negative effects on pork quality traits such as $\mathrm{pH}$ value, water holding capacity, colour, cooking loss, tenderness, and flavour (Dailidavičienè et al., 2008, 2009). As a result of the spreading of lung lesions, the meat has poor processing characteristics, reduced shelf life and a greater ability to support bacterial growth than normal-quality meat (Minkus et al., 2004). Accordingly, meat obtained from pigs with moderate to severe lung lesions does not meet the quality standards to be placed on the meat market and should not be deemed fit for human consumption (Minkus et al., 2004).

Histopathological examination revealed that the main findings in the lungs were acute and chronic interstitial pneumonia. Immunohistochemical examination showed the presence of severe peribronchiolar and perialveolar infiltration in the lungs, composed predominantly of CD3+ T lymphocytes, which is a finding suggestive of pneumonia of viral origin. The assessment highlighted that depending on the presence and severity of lung lesions the carcass value is significantly downgraded, with a remarkable deterioration in pork quality.

\section{Acknowledgement}

This work was supported by the Ministry of Education, Science and Technological Development, Republic of Serbia, Projects No. 31034 and No. III 46002.

\section{References}

Adamović, I., Vitorović, D., Blagojević, M., Nešić, I. and Brkić, Z. (2014): Histological and histochemical properties of $\mathrm{m}$. semitendinosus in German Landrace pigs at birth and market weight. Acta Vet. Beograd 64, 319-326.

Adzitey, F. and Nurul, H. (2011): Pale soft exudative (PSE) and dark firm dry (DFD) meats: causes and measures to reduce these incidences - a mini review. Int. Food. Res. J. 18, 11-20.

Becskei, Zs., Aleksić-Kovačević, S., Rusvai, M., Balka, Gy., Jakab, C., Petrović, T. and Knežević, M. (2010): Distribution of porcine circovirus 2 cap antigen in the lymphoid tissue of pigs affected by postweaning multisystemic wasting syndrome. Acta Vet. Hung. 58, 483-498. 
Čobanović, N., Bošković, M., Vasilev, D., Dimitrijević, M., Parunović, N., Djordjević, J. and Karabasil, N. (2016c): Effects of various pre-slaughter conditions on pig carcasses and meat quality in a low-input slaughter facility. S. Afr. J. Anim. Sci. 46, 380-390.

Čobanović, N., Karabasil, N., Cojkić, A., Vasilev, D. and Stajković, S. (2016a): Carcass quality and hematological alterations associated with lung lesions in slaughter pigs. Scientific Papers Animal Science and Biotechnologies 49, 236-240.

Čobanović, N., Karabasil, N., Ilić, N., Dimitrijević, M., Vasilev, D., Cojkić, A. and Janković, L. (2015): Pig welfare assessment based on presence of skin lesions on carcass and pathological findings in organs. Proceedings of the 17th International Congress on Animal Hygiene, 'Animal Hygiene and Welfare in Livestock Production - The First Step to Food Hygiene', June 7-11, Košice, Slovakia. pp. 26-29.

Čobanović, N., Karabasil, N., Stajković, S., llić, N., Suvajdžić, B., Petrović, M. and Teodorović, V. (2016b): The influence of pre-mortem conditions on pale, soft and exudative (PSE) and dark, firm and dry (DFD) pork meat. Acta Vet. Beograd 66, 176-182.

Dailidavičienė, J., Januškevičienė, G., Jukna, V., Pockevičius, A. and Kerzienė, S. (2008): Typically definable respiratory lesions and their influence on meat characteristics in pigs. Vet. Zootech. Lith. 43, 20-24.

Dailidavičienė, J., Januškevičienè, G., Zaborskiene, G. and Garmiene, G. (2009): Pork quality analysis according to different degree of lung lesions [in German, with English abstract]. Fleischwirtschaft 89, 100-103.

Donkó, T., Kovács, M. and Magyar, T. (2005): Association of growth performance with atrophic rhinitis and pneumonia detected at slaughter in a conventional pig herd in Hungary. Acta Vet. Hung. 53, 287-298.

Fablet, C., Dorenlor, V., Eono, F., Eveno, E., Jolly, J. P., Portier, F. and Rose, N. (2012): Noninfectious factors associated with pneumonia and pleuritis in slaughtered pigs from 143 farrow-to-finish pig farms. Prev. Vet. Med. 104, 271-280.

Flesja, K. I. and Ulvesaeter, H. O. (1980): Pathological lesions in swine at slaughter. III. Interrelationship between pathological lesions, and between pathological lesions and (1) carcass quality and (2) carcass weight. Acta Vet. Scand. Suppl. 74, 1-22.

Fraile, L., Alegre, A., López-Jiménez, R., Nofrarías, M. and Segalés, J. (2010): Risk factors associated with pleuritis and cranio-ventral pulmonary consolidation in slaughter-aged pigs. Vet. J. 184, 326-333.

Harley, S., More, S., Boyle, L., O’Connell, N. and Hanlon, A. (2012): Good animal welfare makes economic sense: potential of pig abattoir meat inspection as a welfare surveillance tool. Irish Vet. J. 65, 1-12.

Henninger, M., Labarque, G., Fily, B. and Auvigne, V. (2014): Quantification of the relation between lung lesions at slaughter and growth performance from birth to slaughter - proposal for a new synthetic indicator [in French, with English abstract]. Journées Recherche Porcine 46, 183-184.

Hillen, S., von Berg, S., Köhler, K., Reinacher, M., Willems, H. and Reiner, G. (2014): Occurrence and severity of lung lesions in slaughter pigs vaccinated against Mycoplasma hyopneumoniae with different strategies. Prev. Vet. Med. 113, 580-588.

Karabasil, N., Dokmanović, M., Dimitrijević, M., Teodorović, V., Kojičić Stefanović, J., Glamočlija, N. and Baltić, Ž. M. (2013a): Assessment of welfare conditions during stunning of pigs with respect to the day of the week [in Serbian, with English abstract]. Meat Technology 54, 89-96.

Karabasil, N., Vasiljević, M., Dimitrijević, M., Vučinić, M., Đorđević, V., Ivanović, J. and Kureljušić, J. (2013b): The study of transport conditions of pigs to the slaughterhouse [in Serbian, with English abstract]. Meat Technology 54, 1-7.

Lukač, B., Knežević, A., Milić, N., Krnjajić, D., Veljović, Lj., Milićević, V., Zorić, A., Đurić, S., Stanojević, M. and Nišavić, J. (2016): Molecular detection of PCV2 and PPV in pigs in Republic of Srpska, Bosna and Herzegovina. Acta Vet. Belgrade 66, 51-60. 
Madec, F. and Kobisch, M. (1982): Bilan lésionnel des poumons de porcs char-cutiers à l'abattoir [in French]. Journées de la Recherche Porcine 14, 405-412.

Minkus, D., Schutte, A., von Mickwitz, G. and Beutling, D. (2004): Lung health, meat content and meat ripening in pigs - defective lungs as a problem in meat inspection [in German, with English abstract]. Fleischwirtschaft 87, 110-113.

Official Gazette (1985): Rules for the classification of pig carcasses (Official Gazette SFRJ, No. 2/85, 12/85, 24/86) [in Serbian].

Ostanello, F., Dottori, M., Gusmara, C., Leotti, G. and Sala, V. (2007): Pneumonia disease assessment using a slaughterhouse lung-scoring method. J. Vet. Med. A 54, 70-75.

Palzer, A., Austin-Busse, R. L., Ladinig, A., Balka, Gy., Spergser, J. and Ritzmann, M. (2015): Different sample types in pigs challenged with Haemophilus parasuis following two treatment schemes with tulathromycin. Acta Vet. Hung. 63, 157-166.

Permentier, L., Maenhout, D., Deley, W., Broekman, K., Vermeulen, L., Agten, S. and Geers, R. (2015): Lung lesions increase the risk of reduced meat quality of slaughter pigs. Meat Sci. 108, 106-108.

Polaček, V. and Aleksić-Kovačević, S. (2016): Mycobacteriosis in pigs - an underestimated threat. Acta Vet. Belgrade 66, 229-243.

Polaček, V., Prodanov, J., Lazić, S., Petrović, T., Rašić, Z. and Aleksić-Kovačević, S. (2007): Immunohistochemical detection of B and T lymphocytes in mandibular lymph nodes of experimentally infected piglets with classical swine fever virus. Acta Vet. Beograd 57, 199-208.

Sárközi, R., Makrai, L. and Fodor, L. (2015): Identification of a proposed new serovar of Actinobacillus pleuropneumoniae: serovar 16. Acta Vet. Hung. 63, 444-450.

Šoltésová, H., Nagyová, V., Tóthová, C. and Nagy, O. (2015): Haematological and blood biochemical alterations associated with respiratory disease in calves. Acta Vet. Brno 84, 249-256.

SPSS (2015): Statistical Package for Social Sciences for Windows (version S23.0). SPSS Inc., Armonk, NY: IBM Corp., USA.

Štukelj, M., Plut, J. and Toplak, I. (2015): Serum inoculation as a possibility for elimination of porcine reproductive and respiratory syndrome (PRRS) from a farrow-to-finish pig farm. Acta Vet. Hung. 63, 389-399.

Szeredi, L., Cságola, A., Dán, Á. and Dencső, L. (2015): Vascular lesions and pneumonia in a pig fetus infected by porcine circovirus type 2. Acta Vet. Hung. 63, 215-222.

Teixeira, D. L., Harley, S., Hanlon, A., O’Connell, N. E., More, S. J., Manzanilla, E. G. and Boyle, L. A. (2016): Study on the association between tail lesion score, cold carcass weight, and viscera condemnations in slaughter pigs. Front. Vet. Sci. 3, 1-7.

Toplak, I., Lazić, S., Lupulović, D., Prodanov-Radulović, J., Becskei, Zs., Došen, R. and Petrović, T. (2012): Study of the genetic variability of porcine circovirus type 2 detected in Serbia and Slovenia. Acta Vet. Hung. 60, 409-420.

Ujvári, B., Szeredi, L., Pertl, L., Tóth, G., Erdélyi, K., Jánosi, Sz., Molnár, T. and Magyar, T. (2015): First detection of Pasteurella multocida type B:2 in Hungary associated with systemic pasteurellosis in backyard pigs. Acta Vet. Hung. 63, 141-156.

van Staaveren, N., Vale, A. P., Manzanilla, E. G., Teixeira, D. L., Leonard, F. C., Hanlon, A. and Boyle, L. A. (2016): Relationship between tail lesions and lung health in slaughter pigs. Prev. Vet. Med. 127, 21-26. 